\title{
Duas tendências de re-africanização: Rio de Janeiro e Salvador
}

Claudia Couto Sigilião

Curso: Doutorado em Sociologia

Data da defesa: 25 de junho de 2009

Orientador: Prof. Dr. Edson Silva de Farias

\section{Resumo}

Analisa o caminho percorrido pelo movimento de reafricanização ocorrido nos anos 70 em duas cidades brasileiras: Rio de Janeiro e Salvador. A questão a ser esclarecida é saber em que medida os rumos tomados pela escravidão no Brasil definiram caminhos possíveis de reafricanização no que diz respeito às expressões lúdico-musicais nessas duas cidades. $\mathrm{O}$ trajeto do negro da escravidão ao movimento de reafricanização surgido nos anos 70 é percorrido, nessa tese, por meio da análise das festas de carnaval e do uso dos seus ritmos percussivos. As escolas de samba da cidade do Rio de Janeiro e os blocos afro da cidade de Salvador elucidam, por meio de seus dois produtos musicais - samba-enredo e sambareggae - como as influências das ações afirmativas ocorridas na música de protesto de outros países, nos anos 50, 60 e 70, tomaram impulso e se espalharam, trazendo consigo mudanças sociais, econômicas, políticas e culturais, inclusive para o Brasil.

A música, como um eficiente veículo de comunicação junto a diferentes parcelas da população brasileira, difunde rapidamente toda e qualquer representação social surgida nas duas cidades como consequência de movimentos sociais, políticos e religiosos, trazendo à tona, com sua linguagem, tanto a busca por afirmação da identidade negra, e todo o processo de mudança da cultura popular 
negro-mestiça, quanto as transformações ocorridas com os gêneros e estilos musicais no processo de reafricanização, redundando em um material musical aparentemente diferente do que existia anteriormente, embora, estruturalmente, a mudança musical não seja tão profunda.

Palavras-chave: re-africanização; música afro-brasileira; cultura popular negro-mestiça; samba-enredo, samba-reggae. 